\title{
BMJ Open Cancer incidence among Finnish ferrochromium and stainless steel production workers in 1967-2011: a cohort study
}

\author{
Markku Huvinen, ${ }^{1}$ Eero Pukkala ${ }^{2,3}$
}

To cite: Huvinen M, Pukkala E. Cancer incidence among Finnish ferrochromium and stainless steel production workers in 1967-2011: a cohort study. BMJ Open 2013;3: doi:10.1136/bmjopen-2013003819

- Prepublication history for this paper is available online. To view these files please visit the journal online (http://dx.doi.org/10.1136/ bmjopen-2013-003819).

Received 15 August 2013 Revised 7 October 2013 Accepted 9 October 2013

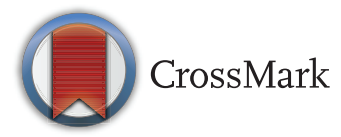

${ }^{1}$ Occupational Health, Outokumpu Oyj, Espoo, Finland

${ }^{2}$ Finnish Cancer Registry, Institute for Statistical and Epidemiological Cancer Research, Helsinki, Finland ${ }^{3}$ School of Health Sciences, University of Tampere, Tampere, Finland

Correspondence to Dr Markku Huvinen; markku. huvinen@outokumpu.com

\section{ABSTRACT}

Objectives: The aim of the study was to assess the risk of cancer among workers employed in the Finnish ferrochromium and stainless steel industry since the beginning of production in 1967.

Methods: The study cohort was made up of all persons employed by the Finnish stainless steel production chain from chromite mining to cold rolling of stainless steel during the period 1967-2004, and it was divided into subcohorts by production units with specific exposure patterns of the subcohorts assessed in previous studies. Follow-up for cancer through the files of the Finnish Cancer Registry was performed using the personal identity code as key. Standardised incidence ratios (SIRs) were calculated as the ratios of observed numbers of cancer cases and numbers expected on the basis of incidence rates in the population of the same region.

Results: The overall cancer incidence was at the expected level. The lung cancer risk was decreased in the whole cohort (SIR $0.79 ; 95 \% \mathrm{Cl} 0.65$ to 1.08 ). The incidence of prostate cancer was significantly increased $(1.31 ; 1.05$ to 1.61$)$ and that for kidney cancer was significantly decreased $(0.38 ; 0.14$ to 0.82$)$. None of the department-specific SIRs for lung cancer were significantly different from 1.0. No cancers of the nose and nasal sinuses were observed among workers in the ferrochromium smelter or the stainless steel melting shop.

Conclusions: It is not likely that the occupational exposures in the Finnish ferrochromium and stainless steel industry would have increased the risk of cancer.

\section{INTRODUCTION}

Stainless steels are defined according to the European Standard EN 10088 as iron-based alloys containing at least $10.5 \%$ chromium and a maximum of $1.2 \%$ carbon. Stainless steels can contain nickel as another major alloying element, with a content of up to $38 \%$. Other possible alloying elements include molybdenum, manganese, silicon and copper. ${ }^{1}$
Strengths and limitations of this study

- The study was based on non-selected national registers with good data accuracy and coverage.

- Long follow-up and complete information on cancer.

- Information on cofactors was not systematically available.

Chromium is encountered mainly in the following three oxidation states: metallic $\left(\mathrm{Cr}^{0}\right)$, trivalent $\left(\mathrm{Cr}^{3+}\right)$ and hexavalent $\left(\mathrm{Cr}^{6+}\right)$. According to the evaluation of the International Agency for Research on Cancer (IARC), metallic chromium and trivalent chromium compounds are not classifiable as to their carcinogenicity to humans. ${ }^{2}$ In 2011, IARC stated that there is sufficient evidence in humans for the carcinogenicity of $\mathrm{Cr}^{6+}$ compounds (group 1). They cause cancer of the lung. ${ }^{3}$ Positive associations have also been observed between exposure to $\mathrm{Cr}^{6+}$ compounds and cancer of the nose and nasal sinuses. Exposure to $\mathrm{Cr}^{6+}$ compounds may occur in certain phases in stainless steel production: in ferrochromium smelting, in stainless steel melting and in the annealing and pickling of cold-rolled stainless steel.

According to IARC evaluation, there is sufficient evidence in humans for the carcinogenicity of mixtures that include nickel compounds and nickel metal. ${ }^{4}$ The evidence is strongest for soluble nickel compounds; there is also independent evidence for the carcinogenicity of oxidic and sulfidic nickel compounds. These agents cause cancers of the lung and of the nose and nasal sinuses. Nickel compounds are carcinogenic to humans (group 1). Exposure to nickelcontaining fumes and dusts may occur mainly in the melting shop stage of stainless steel production. 
The main aim of this study was to assess the risk of cancer, with special reference to cancers of the nose and lung among workers employed in the Finnish ferrochromium and stainless steel industry since the beginning of production in 1967.

\section{SUBJECTS AND METHODS \\ Study design}

The study cohort was made up of all persons employed at the Kemi mine and Tornio production units of Outokumpu Group (called Tornio Works) during the period 1967-2004. The cohort was identified from the company's employment records. An extensive search of the population registers traced the correct personal identity code (PIC), possible emigration date and vital status for all but $9(0.1 \%)$ of the cohort members. Non-residents of Finland were excluded. After the exclusions, the cohort included a total of 8146 workers (table 1). All Finnish residents have had a unique PIC since 1967 that is used in all main registers in Finland. PIC enables reliable automatic record linkage.

Follow-up for cancer through the files of the population-based countrywide Finnish Cancer Registry was performed using PIC as key. Follow-up for cancer started at the date of first employment at Tornio Works, and ended at emigration, death or 31 December 2011, whichever was first. Further division was made by the time elapsed since the first employment.

The cohort was divided into subcohorts by production departments (table 1). Analyses stratified by department were performed in two ways. First, we counted the overall cancer risk starting from first employment in a given department. Second, the follow-up was started from the date when a person had worked for 5 years in a given department.
The numbers of observed cases and person-years at risk were counted, by 5-year age groups, separately for men and women and for nine 5-year calendar periods during 1967-2011. The expected numbers of cases for total cancer and for specific cancer types were calculated by multiplying the number of person-years in each stratum by the corresponding average cancer incidence in the catchment area of Oulu University Hospital in Northern Finland. For comparison purposes, we also calculated SIRs based on expected rates based on reference rates of the whole of Finland.

To calculate SIR, the observed number of cases was divided by the expected number. The $95 \%$ CIs for SIR were based on the assumption that the number of observed cases followed a Poisson distribution.

\section{Exposures}

At the chromite mine in the 1980s, the average exposure to total dust was $1 \mathrm{mg} / \mathrm{m}^{3}$. The highest personal exposures were found in the crushing plant (1.4-4.9 mg/ $\left.\mathrm{m}^{3}\right)$. The chromium content of the dust was $1-5 \%$, which indicates that the median personal exposure to chromium was $22 \mu \mathrm{g} / \mathrm{m}^{3}$. $\mathrm{Cr}^{6+}$ was not detected in any of the samples from the mine. ${ }^{5}$

In the furnace department of the ferrochromium smelter, the median personal dust exposure was $1.5 \mathrm{mg} / \mathrm{m}^{3}$. The median chromium concentration was $143 \mu \mathrm{g} / \mathrm{m}^{3}$. The median personal workplace air concentration of $\mathrm{Cr}^{6+}$ was below the detection limit of the method $\left(0.5 \mu \mathrm{g} / \mathrm{m}^{3}\right.$, maximum $\left.2.4 \mu \mathrm{g} / \mathrm{m}^{3}\right)$. The highest concentrations were detected during tapping in the vicinity of the tap hole, where the proportion of $\mathrm{Cr}^{6+}$ was 10-fold that of other areas. ${ }^{5}$ In an analysis using a field emission scanning electron microscope, the aerosols from the ferrochromium smelter were observed to contain agglomerates of particles

Table 1 Number of persons (N) at Tornio works, and person-years at follow-up during 1967-2011, by work department, age and gender

\begin{tabular}{|c|c|c|c|c|c|c|}
\hline & \multicolumn{2}{|l|}{ Men } & \multicolumn{2}{|c|}{ Women } & \multicolumn{2}{|l|}{ Total } \\
\hline & $\mathbf{N}^{*}$ & Person-years & $\overline{\mathbf{N}^{*}}$ & Person-years & $\overline{\mathbf{N}^{*}}$ & Person-years \\
\hline Total & 6330 & 156296 & 1816 & 40188 & 8146 & 196484 \\
\hline \multicolumn{7}{|l|}{ Department } \\
\hline Chromite mine & 335 & 8894 & 31 & 697 & 366 & 9591 \\
\hline Ferrochromium plant & 820 & 23705 & 28 & 770 & 848 & 24475 \\
\hline Stainless steel melting shop & 682 & 13755 & 21 & 367 & 703 & 14122 \\
\hline Hot rolling mill & 189 & 3329 & 27 & 435 & 216 & 3764 \\
\hline Cold rolling mill & 1648 & 34115 & 262 & 5198 & 1910 & 39312 \\
\hline Maintenance and services & 2132 & 58856 & 852 & 18606 & 2984 & 77462 \\
\hline Metallurgical laboratory & 303 & 7824 & 147 & 3269 & 450 & 11093 \\
\hline Office & 221 & 5818 & 448 & 10847 & 669 & 16665 \\
\hline \multicolumn{7}{|l|}{ Age } \\
\hline$<30$ & 5400 & 43922 & 1536 & 14178 & 6936 & 58099 \\
\hline $30-44$ & 829 & 66155 & 227 & 15602 & 1056 & 81756 \\
\hline $45-59$ & 98 & 36434 & 52 & 7944 & 150 & 44378 \\
\hline $60-74$ & 3 & 9085 & 1 & 2097 & 4 & 11182 \\
\hline $75+$ & - & 700 & - & 369 & - & 1069 \\
\hline
\end{tabular}


with a diameter of less than $1 \mu \mathrm{m}$. Chromium seemed to be dissolved in a silica matrix. Most of the particles were covered with a thin layer of zinc oxide. Zinc originates from the ore. Owing to its low melting point, zinc is the last condensate on the surface of the particles. ${ }^{6}$

The average exposure to total dust in the stainless steel melting shop was $1.8 \mathrm{mg} / \mathrm{m}^{3}$. The dust contained $2-4 \%$ chromium. The median content of total chromium in the personal samples collected from the breathing zone was $30 \mu \mathrm{g} / \mathrm{m}^{3}$. The median $\mathrm{Cr}^{6+}$ level was $0.5 \mu \mathrm{g} / \mathrm{m}^{3}$. The highest figures of $\mathrm{Cr}^{6+}$ among personal samples were detected in the handling of molten metal by the arc furnace $\left(6.6 \mu \mathrm{g} / \mathrm{m}^{3}\right)$. Although $\mathrm{Cr}^{6+}$ seemed to be present at low concentrations almost all over the steel melting shop, it exceeded the detection limit of $0.5 \mu \mathrm{g} / \mathrm{m}^{3}$ only in some of the personal samples. The particles in the aerosols encountered in the stainless steel melting shop were predominantly metal alloys. No pure chromium or nickel particles were observed. The particles had an iron core surrounded by chromium and nickel as alloys and silicates and oxides. ${ }^{6}$ In an analysis using scanning electron microscopy, energydispersive X-ray spectroscopy and X-ray diffraction, the composition of the metal particles generated in the melting process and released to the ambient air were observed to resemble stainless steel. ${ }^{7}$

In the grinding shop, the average exposure to total dust was $0.8 \mathrm{mg} / \mathrm{m}^{3}$. The median chromium content was $66 \mu \mathrm{g} / \mathrm{m}^{3}$. The median $\mathrm{Cr}^{6+}$ level was below $0.5 \mu \mathrm{g} / \mathrm{m}^{3}$ (maximum $0.6 \mu \mathrm{g} / \mathrm{m}^{3}$ ).

The total dust content was low throughout the cold rolling mill, averaging $0.3-0.5 \mathrm{mg} / \mathrm{m}^{3}$, and the highest measured single concentration was $1.8 \mathrm{mg} / \mathrm{m}^{3}$. In general, the content of chromium in the air in the cold rolling mill was lower than the detection limit of the measurement method. $\mathrm{Cr}^{6+}$ was found only in the annealing and pickling line, in the neutralisation and acid regeneration shop and near some automatic welding machines. The median $\mathrm{Cr}^{6+}$ concentration was below $0.5 \mu \mathrm{g} / \mathrm{m}^{3}$ (maximum $6.6 \mu \mathrm{g} / \mathrm{m}^{3}$ ).

The continuous monitoring system for dust exposure has shown that the concentrations of chromiumcontaining dusts in the workplace air decreased at a rate of $17 \%$ from 1970 to the early 1990s in the mine, the ferrochromium works and the stainless steel melting shop. In the cold rolling mill, the concentrations have always been very low.

In the stainless steel melting shop, nickel and molybdenum are added as alloying metals. The median ambient air concentration of nickel was $1.8 \mu \mathrm{g} / \mathrm{m}^{3}$ (maximum $9.4 \mu \mathrm{g} / \mathrm{m}^{3}$ ) in the personal samples and $3.1 \mu \mathrm{g} / \mathrm{m}^{3}$ (maximum $30.0 \mu \mathrm{g} / \mathrm{m}^{3}$ ) in the stationary samples. ${ }^{8}$

The Finnish Meteorological Institute carried out an outdoor air quality monitoring programme within the industrial area of Outokumpu Tornio Works. The continuous programme covered 4 months in 2011. The mean concentration of chromium in the respirable particles $\left(\mathrm{PM}_{10}\right)$ was $181 \mathrm{ng} / \mathrm{m}^{3}$. The respective figure for nickel was $77 \mathrm{ng} / \mathrm{m}^{3}$.

Asbestos, crystalline silica. polycyclic aromatic hydrocarbons and ionising radiation have also been classified as carcinogenic to humans. ${ }^{10-13}$

Asbestos containing materials were used in thermal insulators and in construction materials in the early decades of production. Limited areas in the ore body and the waste rock of the chromite mine contained crevices filled with chrysotile in the 1980s. Thus, sporadic exposure peaks among workers have been possible. Exposure to quartz and benzo(a)pyrene (PAHs) may occur in the ferrochromium smelter.

The main raw material in the stainless steel melting shop is recycled steel, which may include radioactive material. Despite strict online radiation security screening, some small sources of radiation may accidentally, but rarely, enter the melting process. A typical example of radioactive materials is americium, which is used in industrial measuring devices and smoke detectors. Americium ends up in the stainless steel melting shop ambient air via slag. In the conducted individual measurements, not a single incidental personal radiation dose has, however, exceeded the limit level given by the national radiation authorities.

\section{RESULTS}

There were 6330 men and 1816 women under follow-up in the cohort. The numbers of person-years were 156000 and 40000 , respectively (table 1 ). The mean length of follow-up of a person was thus 24.1 years.

During the follow-up period, of the 408 cases of cancer that were diagnosed, the expected number was 396 (table 2). The SIR of cancer was 1.03 (95\% CI 0.93 to 1.13) using people living in Northern Finland as the reference population. The SIR was 0.94 (95\% CI 0.86 to 1.03) when the expected number of cancer cases (432) for the whole country was used as reference.

Among the total cohort members, the observed number of lung cancer cases was 37 (SIR $0.79,95 \%$ CI 0.65 to 1.08 ). Among those members of the cohort who had been working in the same department for more than 5 years, the SIR was 0.72 (95\% CI 0.44 to 1.12) (table 3). None of the department-specific SIRs for lung cancer was significantly different from 1.0 (table 3).

Two cancers of the nose were observed (SIR 2.05, 95\% CI 0.25 to 7.42), both among men. One of them had been working in the concentration department of the chromite mine for 9 months, and the other in the sintering plant for 3 months in the 1970s.

There were no cases of mesothelioma. The expected number for the whole cohort was 0.37 .

From the other sites, only the incidence of prostate cancer was significantly increased (SIR 1.31, 95\% CI 1.05 to 1.61 ), and only the incidence of kidney cancer was significantly decreased (SIR $0.38,95 \%$ CI 0.14 to 0.82) (table 2). 
Table 2 Observed (Obs) and expected (Exp) numbers of cancer cases and standardised incidence ratios (SIR) with 95\% Cls among workers at Tornio Works during 1967-2011, by site

\begin{tabular}{|c|c|c|c|c|}
\hline Primary site Exp SIR $95 \%$ CI & Obs & Exp & SIR & $95 \% \mathrm{Cl}$ \\
\hline All sites & 408 & 395.8 & 1.03 & 0.93 to 1.13 \\
\hline Mouth, pharynx & 12 & 10.3 & 1.16 & 0.60 to 2.03 \\
\hline Oesophagus & 4 & 4.6 & 0.86 & 0.24 to 2.20 \\
\hline Stomach & 12 & 14.9 & 0.80 & 0.42 to 1.40 \\
\hline Colon & 22 & 16.8 & 1.30 & 0.82 to 1.97 \\
\hline Rectum & 14 & 13.3 & 1.06 & 0.58 to 1.77 \\
\hline Liver & 4 & 5.2 & 0.78 & 0.21 to 1.98 \\
\hline Gallbladder & 4 & 2.5 & 1.58 & 0.43 to 4.03 \\
\hline Pancreas & 16 & 13.1 & 1.22 & 0.70 to 1.98 \\
\hline Nose, sinuses & 2 & 1.0 & 2.05 & 0.25 to 7.42 \\
\hline Larynx & 4 & 3.4 & 1.19 & 0.33 to 3.05 \\
\hline Lung, bronchus & 37 & 47.0 & 0.79 & 0.55 to 1.08 \\
\hline Breast & 31 & 30.8 & 1.01 & 0.68 to 1.42 \\
\hline Cervix uteri & 20 & 16.7 & 1.20 & 0.73 to 1.85 \\
\hline Corpus uteri & 7 & 4.5 & 1.54 & 0.62 to 3.18 \\
\hline Ovary & 2 & 4.0 & 0.50 & 0.06 to 1.81 \\
\hline Prostate & 89 & 67.8 & 1.31 & 1.05 to $1.61^{*}$ \\
\hline Testis & 5 & 6.4 & 0.78 & 0.25 to 1.83 \\
\hline Kidney & 6 & 15.8 & 0.38 & 0.14 to $0.82^{\star *}$ \\
\hline Bladder & 14 & 14.0 & 1.00 & 0.55 to 1.67 \\
\hline Skin melanoma & 24 & 16.7 & 1.44 & 0.92 to 2.14 \\
\hline Other skin & 5 & 7.6 & 0.66 & 0.21 to 1.53 \\
\hline Brain/nervous system & 18 & 19.3 & 0.93 & 0.55 to 1.47 \\
\hline Thyroid & 10 & 13.7 & 0.73 & 0.35 to 1.34 \\
\hline Soft tissue & 3 & 3.7 & 0.82 & 0.17 to 2.40 \\
\hline Hodgkin lymphoma & 3 & 5.8 & 0.52 & 0.11 to 1.50 \\
\hline Non-Hodgkin lymphoma & 24 & 19.1 & 1.26 & 0.81 to 1.87 \\
\hline Multiple myeloma & 6 & 4.6 & 1.32 & 0.48 to 2.86 \\
\hline Leukaemia & 15 & 11.5 & 1.31 & 0.73 to 2.15 \\
\hline Not included above: skin, basal cell carcinoma & 88 & 70.3 & 1.25 & 1.00 to $1.54^{*}$ \\
\hline
\end{tabular}

The only department which showed increased cancer incidence was the chromite mine. The overall cancer incidence among those with at least 5 years of employment at the chromite mine was non-significantly increased (SIR 1.48 , 95\% CI 0.88 to 2.33 ; table 3), but the SIR for those with less than 5 years of employment had an SIR of 1.84 (95\% CI 1.09 to $2.90, \mathrm{p}<0.05 ; 18$ observed cases) and raised the SIR for all workers who had ever worked at the chromite mine to 1.64 (95\% CI 1.15 to $2.26, \mathrm{p}<0.01)$. There were altogether five cases of alcohol-related cancers (tongue, mouth, pharynx, liver and pancreas) ${ }^{14}$ versus 1.4 expected (SIR $3.57,95 \%$ CI 1.16 to 8.33 ). The incidence of rectal cancer was also significantly increased (SIR 5.06, 95\% CI 1.38 to 12.9), while there was only one case of lung cancer (SIR 0.33 , $95 \%$ CI 0.01 to 1.84 ).

\section{DISCUSSION}

Our cohort consisted of all employees who had been working at the integrated production unit of Tornio Works during 1967-2004. Identification of cohort members and follow-up for deaths and emigration are complete for the period of this study. The completeness of cancer registration in Finland is at least $99 \%,{ }^{15}$ and the computerised record linkage procedure precise. ${ }^{16}$ Therefore, technical incompleteness does not cause bias in the results.

\section{Overall cancer}

The overall cancer incidence was not elevated in the present study. We used as the main reference the incidence rates of the population of Northern Finland because the incidence rates vary geographically. Cancer incidence also varies according to socioeconomic position. The majority of the workers in the departments at Tornio Works belong to the category of skilled bluecollar workers who have an average or slightly elevated overall cancer incidence as compared to the average population. ${ }^{17}$

A slightly increased incidence of cancer (SIR 1.16) was observed in a Norwegian study among ferrochromium workers. ${ }^{18}$ Decreased cancer mortality was observed in a Swedish study in ferrochromium production ${ }^{19}$ and studies in the French stainless steel industry. ${ }^{20-22}$ 
Table 3 Observed (Obs) and expected (Exp) numbers of cancer cases (all sites, lung and nasal cancer) and standardised incidence ratios (SIR) with 95\% Cl during 1967-2011 among workers at Tornio Works with employment $>5$ years, by department

\begin{tabular}{|c|c|c|c|c|c|c|c|c|c|c|c|c|}
\hline \multirow[b]{2}{*}{ Department } & \multicolumn{4}{|c|}{ All sites } & \multicolumn{4}{|c|}{ Lung cancer } & \multicolumn{4}{|c|}{ Nasal cancer } \\
\hline & Obs & Exp & SIR & $95 \% \mathrm{Cl}$ & Obs & Exp & SIR & $95 \% \mathrm{Cl}$ & Obs & Exp & SIR & $95 \% \mathrm{Cl}$ \\
\hline Chromite mine & 18 & 12.2 & 1.48 & 0.88 to 2.33 & 1 & 1.8 & 0.55 & 0.01 to 3.04 & 0 & 0.03 & 0.00 & 0.00 to 137 \\
\hline Sintering plant & 9 & 11.0 & 0.82 & 0.37 to 1.55 & 1 & 1.8 & 0.57 & 0.01 to 3.17 & 0 & 0.03 & 0.00 & 0.00 to 145 \\
\hline Ferrochromium smelter & 17 & & 0.95 & 0.55 to 1.52 & 4 & 2.8 & 1.41 & 0.38 to 3.61 & 0 & 0.04 & 0.00 & 0.00 to 89.2 \\
\hline Stainless steel melting shop & 20 & 19.3 & 1.03 & 0.63 to 1.59 & 2 & 2.6 & 0.76 & 0.09 to 2.76 & 0 & 0.05 & 0.00 & 0.00 to 72.2 \\
\hline & 3 & 4.4 & 0.68 & 0.14 to 1.98 & 1 & 0.5 & 1.95 & 0.05 to 10.9 & 0 & 0.01 & 0.00 & 0.00 to 272 \\
\hline Cold rolling mill & 42 & 43.4 & 0.97 & 0.70 to 1.30 & 2 & 5.1 & 0.39 & 0.05 to 1.40 & 0 & 0.01 & 0.00 & 0.00 to 34.6 \\
\hline Maintenance & 31 & 33.2 & 0.93 & 0.64 to 1.32 & 2 & 5.2 & 0.39 & 0.05 to 1.39 & 0 & 0.07 & 0.00 & 0.00 to 50.0 \\
\hline Total & 207 & 202.6 & 1.02 & 0.89 to 1.16 & 19 & 26.3 & 0.72 & 0.44 to 1.12 & 0 & 0.44 & 0.00 & 0.00 to 8.37 \\
\hline
\end{tabular}

The only department with an increased cancer incidence was the chromite mine, but the excess was mainly seen among the short-term workers. Such a finding is common in the industrial worker cohorts and has been interpreted to reflect a general lifestyle with negative health habits. ${ }^{23}$ There was a significant excess of alcoholrelated cancers among workers in the chromite mine in our study. Among the mine workers there is no exposure to $\mathrm{Cr}^{6+}$ or special chemicals. The concentration process is based on the specific gravity of various minerals in the ore body. It seems unlikely that the cancer risk pattern would be strongly associated with occupational exposures at the chromite mine.

\section{Lung cancer}

In the present study the incidence of lung cancer cases was decreased by one-fifth, and even more among those cohort members who had been working in the same department for more than 5 years.

No excess of respiratory cancer mortality was found among men who had been employed in a Swedish ferrochromium plant for at least 1 year during 1930-1974, with an estimated exposure to $\mathrm{Cr}^{6+}$ of $0.25 \mathrm{mg} / \mathrm{m}^{3}$ near the electric arc furnaces. The incidence of cancer of the trachea, bronchus, lung and pleura was not elevated among workers at the arc furnaces, but the incidence of these respiratory cancers was significantly increased among maintenance workers. ${ }^{19}$

Low proportional mortality from lung cancer was reported from US stainless steel production workers by Cornell $^{24}$ in 1984.

A statistically significant increase in lung cancer incidence was observed among Finnish nickel smelter workers exposed to insoluble nickel compounds, with a latency of 20 years. $^{25}$ In that cohort, the mean personal levels of exposure to nickel varied between 0.02 and $0.2 \mathrm{mg} / \mathrm{m}^{3}$. Exposure to nickel is encountered at Tornio Works only in the stainless steel melting shop, where the median exposure level in the $1990 \mathrm{~s}$ was $0.002 \mathrm{mg} / \mathrm{m}^{3}$.

A mortality study at a French plant producing ferrochromium and stainless steel (2269 men employed for at least 1 year from 1952 to 1982) showed a non-significant excess of lung cancer mortality (SMR 1.40, 95\% CI 0.72 to 2.45$).{ }^{20}$ In another stainless steel plant with 4227 workers who had been employed for at least 3 years during 1968-1984, there was a small increase of lung cancer mortality, which was due to a significant increase among the foundry workers (SMR 2.3, 95\% CI 1.1 to 4.1). ${ }^{21}$ Lung cancer mortality among ferroalloy production workers and among workers involved in stainless steel melting and casting was close to expectation. ${ }^{21}$

In a third French cohort with workers exposed to metals in the production of stainless steel and metal alloys during 1968-1992, the mortality from lung cancer was slightly elevated. ${ }^{22}$ A case-control study nested within this cohort failed to detect any relationship between lung cancer and exposure to iron, chromium, nickel and/or their compounds, while high and statistically significant relative risks, along with increasing trends, were observed for simultaneous exposure to PAHs and silica.

In a Norwegian ferrochromium plant, the incidence of lung cancer showed a non-significant, at least, 1.5-fold excess. ${ }^{18}$ The ferrochromium furnace operators worked in an atmosphere with from 0.04 to $24 \mathrm{mg} / \mathrm{m}^{3}$ total chromium. The proportion of $\mathrm{Cr}^{6+}$ was estimated to be $11-33 \%$. The exposure levels to $\mathrm{Cr}^{6+}$ in the Norwegian ferrochromium smelter were up to 40-fold higher compared to the Finnish smelter.

There are several reasons why the results on lung cancer risk may vary between the cohorts. One of the reasons may be the registration of lung cancer. Registration of cancer in the Nordic countries is on such a high level ${ }^{26}$ that we can assume that the events on cancer incidence in the Finnish, Norwegian and Swedish studies are recorded correctly. When it comes to cancer incidence in other countries, or cancer mortality statistics in any country, the possibility of incomplete registration and inaccurate disease classification increases.

The most important source for incomparability between the cohorts is confounding due to smoking, which has not been controlled for in most studies and may lead to a bias to different direction, depending on whether smoking in the cohort is lower or higher than 
in the reference population. The prevalence of smokers among the male employees of Tornio Works in 1993 varied from $28 \%$ in the ferrochromium smelter and stainless steel melting shop to $58 \%$ in the chromite mine $^{27}$ and in 1998 from $27 \%$ in the ferrochromium smelter and the stainless steel melting shop to $43 \%$ in the cold rolling mill. ${ }^{8}$ The prevalence of smokers in the male population in the province of Lapland in Northern Finland in 1990-2005 varied from 20\% in the highest educational class to $42 \%$ in the lowest one. ${ }^{28}$ Hence, the confounding due to smoking should not be large in our study.

Finally, the industrial processes and true exposures may vary. For instance, the ferrochromium electric arc furnaces in Norway were either open or semiclosed furnaces while the Finnish furnaces are fully closed ones with reducing conditions within the furnace. This technological feature explains why the exposure levels to $\mathrm{Cr}^{6+}$ were substantially higher in the Norwegian cohorts (variation $13-8000 \mu \mathrm{g} / \mathrm{m}^{3}$ ) compared to the Finnish one (median below $0.05 \mu \mathrm{g} / \mathrm{m}^{3}$ and maximum $2.4 \mu \mathrm{g} / \mathrm{m}^{3}$ ).

\section{Cancer of the nose and nasal sinuses}

We observed two cases of nasal cancer, both among persons with no exposure to nickel or $\mathrm{Cr}^{6+}$. Hence, these cases cannot be linked to occupational exposures at Tornio Works. As a comparison, among workers in a Finnish nickel refinery who were exposed primarily to nickel sulfate at levels below $0.5 \mathrm{mg} / \mathrm{m}^{3}$ as well as to low concentrations of other nickel compounds, there were also two cases of nasal cancer (40-fold increased risk), both of them after a latency of $>20$ years and long duration of employment. ${ }^{25}$

\section{Other cancers}

In the present study we did not see an excess risk of stomach cancer, similar to the one seen in the French study among ferrochromium and stainless steel workers (SMR $1.57,95 \%$ CI 0.43 to 4.03$)^{20}$ and the Finnish nickel refinery cohort (SIR 5.0, 95\% CI 1.6 to 11.6 ).$^{25}$

In the Norwegian study, ${ }^{18}$ a $60 \%$ non-significant excess was observed for kidney cancer. The present study, instead, showed a significantly decreased risk for cancer of the kidney. A low risk of kidney cancer was also reported for the US stainless steel production workers in the proportional mortality analysis by Cornell ${ }^{24}$ in 1984 . There is no evident explanation for the low risk of kidney cancer, but it is worth mentioning that the work in most departments of Tornio Works some decades ago included much physical activity, and high physical activity has been sometimes connected with a very low risk of kidney cancer. ${ }^{29}$

In the Norwegian study, a $56 \%$ excess was observed for prostate cancer. ${ }^{18}$ The present study showed a significant $30 \%$ increased incidence of prostate cancer. This could be explained by intensified screening and improved early diagnostic methods. Prostate-specific antigen testing in the Nordic countries started in the 1990s in
Sweden, and in Finland it first became common in the Tornio region next to the Swedish border, ${ }^{30}$ which may well have lead to an increased incidence of prostate cancer diagnoses.

As a conclusion, the exposure levels are low, and it is not likely that the occupational exposures in the Finnish ferrochromium and stainless steel industry would have increased the risk of cancer.

Acknowledgements The authors thank MD Aki Kanervo, MD Armi Terho and Ms Riitta Ervasti for assistance in collection of personal data.

Contributors $\mathrm{MH}$ coordinated the collection of cohort personal data. EP performed the statistical analyses. Both authors interpreted the data and approved the final manuscript. EP is the guarantor.

Funding This research received no specific grant from any funding agency in the public, commercial or not-for-profit sectors.

Competing interests $\mathrm{MH}$ has been employed by Outokumpu Group since 1975.

Ethics approval National Institute for Health and Welfare.

Provenance and peer review Not commissioned; externally peer reviewed..

Data sharing statement No additional data are available.

Open Access This is an Open Access article distributed in accordance with the Creative Commons Attribution Non Commercial (CC BY-NC 3.0) license, which permits others to distribute, remix, adapt, build upon this work noncommercially, and license their derivative works on different terms, provided the original work is properly cited and the use is non-commercial. See: http:// creativecommons.org/licenses/by-nc/3.0/

\section{REFERENCES}

1. Cross HJ, Beach J, Levy LS, et al. Manufacture, processing and use of stainless steel: a review of the health effects. Brussels: European Confederation of Iron and Steel Industries (EUROFER), 1999.

2. International Agency for Research on Cancer. Chromium, nickel and welding. IARC Monogr Eval Carcinog Risks Hum 1990;49:49-214.

3. International Agency for Research on Cancer. A review of human carcinogens: arsenic, metals, fibres and dusts. IARC Monogr Eval Carcinog Risks Hum 2012;100C:147-64.

4. International Agency for Research on Cancer. A review of human carcinogens: arsenic, metals, fibres and dusts. IARC Monogr Eval Carcinog Risks Hum 2012;100C:169-211.

5. Huvinen M, Kiilunen M, Oksanen L, et al. Exposure to chromium and its evaluation by biological monitoring in the production of stainless steel. J Occup Med Toxicol 1993;2:205-16.

6. Huvinen M. Surface structure and speciation of metal aerosols: a key to the understanding of their biological effects. In: Ebdon $\mathrm{L}$, Pitts L, Cornelis R, Crews H, Donard OFX, Quevauviller P, eds. Trace element speciation for environment food and health. The Royal Society of Chemistry, 2001:308-14.

7. Huvinen M, Oksanen L, Taikina-aho O. Long-term dust exposure and metal particle characterization in stainless steel melting [abstract]. In: Proceedings of 7th International Symposium on Modern Principles of Air Monitoring and Biomonitoring; 19-23 June 2011. Loen, Norway, 2011:55.

8. Huvinen M, Uitti J, Oksa P, et al. Respiratory health effects of long-term exposure to different chromium species in stainless steel production. Occup Med 2002;52:203-12.

9. Saari H, Alaviippola B, Pesonen R. [Air quality measurements at Outokumpu's industrial site in Tornio] (In Finnish). The Finnish Meteorogical Institute, 2012.

10. International Agency for Research on Cancer. A review of human carcinogens: arsenic, metals, fibres and dusts. IARC Monogr Eval Carcinog Risks Hum 2012;100C:219-307.

11. International Agency for Research on Cancer. A review of human carcinogens: arsenic, metals, fibres and dusts. IARC Monogr Eval Carcinog Risks Hum 2012;100C:355-405.

12. International Agency for Research on Cancer. Some non-heterocyclic polycyclic aromatic hydrocarbons and some related exposures. IARC Monog Eval Carcinog Risks Hum 2010;92:754-73. 
13. International Agency for Research on Cancer. Ionizing radiation, part 2: some internally deposited radionuclides. IARC Monog Eval Carcinog Risks Hum 2001;78:478-80.

14. Dreyer L, Winther JF, Andersen A, et al. Alcohol consumption. APMIS 1997;105 (Suppl 76):48-67.

15. Teppo L, Pukkala E, Lehtonen M. Data quality and quality control of a population-based cancer registry. Experience in Finland. Acta Oncol 1994;33:365-9.

16. Pukkala E. Biobanks and registers in epidemiological research on cancer. In: Dillner J. ed Methods in biobanking. Methods in molecular biology. Vol 675. Totowa: Humana Press, 2011:127-64.

17. Pukkala E, Martinsen JI, Lynge E, et al. Occupation and cancerfollow-up of 15 million people in five Nordic countries. Acta Oncol 2009;48:646-790.

18. Langård S, Andersen A, Ravnestad J. Incidence of cancer among ferrochromium and ferrosilicon workers: an extended observation period. Br J Ind Med 1990;47:14-19.

19. Axelsson G, Rylander R, Schmidt A. Mortality and incidence of tumours among ferrochromium workers. $\mathrm{Br} J$ Ind Med 1980;27:121-7.

20. Moulin JJ, Portefaix P, Wild P, et al. Mortality study among workers producing ferroalloys and stainless steel in France. $\mathrm{Br} \mathrm{J}$ Ind Med 1990;47:537-43.

21. Moulin JJ, Wild $P$, Mantout $B$, et al. Mortality from lung cancer and cardiovascular diseases among stainless steel producing workers. Cancer Causes Control 1993;4:75-81.
22. Moulin JJ, Clavel T, Roy D, et al. Risk of lung cancer in workers producing stainless steel and metallic alloys. Int Arch Occup Environ Health 2000;73:171-80.

23. Boffetta $\mathrm{P}$, Sali $\mathrm{D}$, Kolstad $\mathrm{H}$, et al. International agency for research on cancer. Mortality of short-term workers in two international cohorts. J Occup Environ Med 1998;40:1120-6.

24. Cornell RG. Mortality patterns among stainless steel workers. IARC Sci Publ 1984;53:65-71.

25. Anttila A, Pukkala E, Aitio A, et al. Update of cancer incidence among workers at a copper/nickel smelter and nickel refinery. Int Arch Occup Environ Health 1998;71:245-50.

26. Engholm G, Ferlay J, Christensen N, et al. NORDCAN-a Nordic tool for cancer information, planning, quality control and research. Acta Oncol 2010;49:725-36.

27. Huvinen M, Uitti J, Zitting A, et al. Respiratory health of workers exposed to low levels of chromium in stainless steel production. Occup Environ Med 1996;53:741-7.

28. Helakorpi S, Laitalainen E, Absetz $\mathrm{P}$, et al. [Health behaviour and health among Finnish adults in the Finnish regions in 1978-2005] (In Finnish, with English abstract). National Public Health Institute, 2007;B15:14.

29. Pukkala E, Kaprio J, Koskenvuo M, et al. Cancer incidence among Finnish world class male athletes. Int J Sports Med 2000;21:216-20.

30. Patama T, Engholm G, Klint $\AA$, et al. Small-area based map animations of cancer incidence in the Nordic countries 1971-2010. Nordic Cancer Union, 2013. http://astra.cancer.fi/cancermaps/Nordic 